\title{
Article \\ Phenolic Constituents of Chinese Quince Twigs (Chaenomeles sinensis Koehne) and Their Anti-Neuroinflammatory, Neurotrophic, and Cytotoxic Activities
}

\author{
Dong Hyun Kim ${ }^{1}$, Lalita Subedi ${ }^{2}{ }^{(}$, Hye Ryeong Kim ${ }^{1}$, Sang Un Choi ${ }^{3}$, Sun Yeou Kim ${ }^{2,4}{ }^{(1)}$ and \\ Chung Sub Kim $1,5, *$ (D) \\ 1 School of Pharmacy, Sungkyunkwan University, Suwon 16419, Korea; eodrnduf1@skku.edu (D.H.K.); \\ khryoung@skku.edu (H.R.K.) \\ 2 Gachon Institute of Pharmaceutical Science, Gachon University, Incheon 21936, Korea; \\ subedilali@gmail.com (L.S.); sunnykim@gachon.ac.kr (S.Y.K.) \\ 3 Korea Research Institute of Chemical Technology, Daejeon 34114, Korea; suchoi@krict.re.kr \\ 4 College of Pharmacy, Gachon University, \#191, Hambakmoero, Yeonsu-gu, Incheon 21936, Korea \\ 5 Department of Biopharmaceutical Convergence, Sungkyunkwan University, Suwon 16419, Korea \\ * Correspondence: chungsub.kim@skku.edu; Tel.: +82-31-290-7727
}

\section{check for}

updates

Citation: Kim, D.H.; Subedi, L.; Kim H.R.; Choi, S.U.; Kim, S.Y.; Kim, C.S. Phenolic Constituents of Chinese Quince Twigs (Chaenomeles sinensis Koehne) and Their Anti-Neuroinflammatory, Neurotrophic, and Cytotoxic Activities. Antioxidants 2021, 10, 551. https://doi.org/10.3390/ antiox10040551

Academic Editor: Alfredo Aires

Received: 8 March 2021

Accepted: 30 March 2021

Published: 2 April 2021

Publisher's Note: MDPI stays neutral with regard to jurisdictional claims in published maps and institutional affiliations.

Copyright: (c) 2021 by the authors. Licensee MDPI, Basel, Switzerland. This article is an open access article distributed under the terms and conditions of the Creative Commons Attribution (CC BY) license (https:/ / creativecommons.org/licenses/by/ $4.0 /)$.

\begin{abstract}
Chaenomeles sinensis has been used as a food and traditional medicines. However, most of research on discovering bioactive constituents from this plant have been focused on its yellow fruit, Chinese quince, due to its wide usage. Here, we isolated and characterized three new phenolic compounds (1, 9, and 11) and 21 known compounds $(\mathbf{2}-\mathbf{8}, \mathbf{1 0}$, and 12-24) from the twigs of $C$. sinensis. Their chemical structures were established by spectroscopic and spectrometric data analysis including 1D and 2D NMR, high-resolution mass spectrometry (HRMS), electronic circular dichroism (ECD), and LC-MS analysis. Some of the isolated compounds (1-24) showed anti-neuroinflammatory effects on nitric oxide (NO) production in lipopolysaccharide (LPS)-activated BV-2 cells, neurotrophic activity in C6 cells through the secretion of nerve growth factor (NGF) and/or cytotoxicity against four human cancer cell lines (A549, SK-OV-3, SK-MEL-2, MKN-1).
\end{abstract}

Keywords: Chaenomeles sinensis; Rosaceae; phenolic constituents; anti-inflammation; neurotrophic effect; cytotoxicity

\section{Introduction}

Phenolic compounds are one of the largest natural products groups, especially in the plant kingdom, and are characterized by the presence of at least a benzene ring with hydroxy group(s) attached to it [1]. They can be classified into several subgroups according to the number of carbon atoms and their arrangement as follows: phenolic acids $\left(\mathrm{C}_{6}-\mathrm{C}_{1}\right)$, acetophenones and phenylacetic acids $\left(C_{6}-C_{2}\right)$, phenylpropanoids $\left(C_{6}-C_{3}\right)$, naphthoquinones $\left(\mathrm{C}_{6}-\mathrm{C}_{4}\right)$, xanthones $\left(\mathrm{C}_{6}-\mathrm{C}_{1}-\mathrm{C}_{6}\right)$, stilbenoids $\left(\mathrm{C}_{6}-\mathrm{C}_{2}-\mathrm{C}_{6}\right)$, flavonoids $\left(\mathrm{C}_{6}-\mathrm{C}_{3}-\mathrm{C}_{6}\right)$, and lignans $\left(C_{6}-C_{3}-C_{3}-C_{6}\right)[1,2]$. Many of these well-known natural products in the phenolic compounds class have been reported to possess diverse pharmacological activities including anti-inflammatory (e.g., salicylic acid), neurotrophic (e.g., 6-shogaol) [2,3], antioxidant (e.g., resveratrol, quercetin) [2], and anticancer (e.g., podophyllotoxin) [2] effects.

Neurodegenerative diseases such as dementia and Parkinson's disease are exploding due to rapid aging populations [4]. Despite various efforts to overcome these neurodegenerative diseases, there are not sufficient reports on drugs that modify the disease [5]. Therefore, it is very important to draw meaningful leading compounds from natural resources in order to regulate neurodegenerative diseases. As neurodegenerative diseases are highly complex and incurable things, there are some aspects that make it difficult to overcome diseases with a single target such as amyloid beta [5]. Thus, we should think about the study of exploring phytochemicals that overcome neurodegenerative diseases by regulating 
multiple targets. In this study, the effects of phytochemicals with anti-neuroinflammation and neurotrophic factor potentiation will be shown. They are important multi-targets that cause the induction and progression of neurodegenerative diseases.

Chaenomeles sinensis Koehne (or Pseudocydonia sinensis, Chinese Quince, Rosaceae) is a semi-evergreen tree in the family Rosaceae and is widely distributed in East Asia, including Korea, mainland China, and Japan. The yellow fruit of this plant has been consumed as a tea, in a candied form, or in liquor [6], and also used as a Korean traditional medicine over 400 years to treat myalgia, beriberi, vomiting, and diarrhea [7]. Due to the wide range of usages of $C$. sinensis fruit, the phytochemical and biological research on this plant has been mainly focused on the fruit [8-13] rather than the other parts such as twigs $[14,15]$ or leaves. Based on these previous studies, it was found that the major compound classes of $C$. sinensis were triterpenoids $[9,14-16]$ and flavonoids $[8,13,15]$. However, minor components such as non-flavonoid phenolic compounds in the $C$. sinensis twigs with anti-neurodegerative effects remain largely unknown. In this study, 24 phenolic compounds (1-24) including three new compounds $(\mathbf{1}, \mathbf{9}$, and 11) were isolated and characterized from the twigs of $C$. sinensis (Figure 1). Their structures were elucidated by conventional NMR techniques coupled with simulation of ${ }^{1} \mathrm{H}$ NMR peak, analysis of HRMS and ECD data, and hydrolysis followed by LC-MS analysis. The isolates (1-24) were tested for their anti-neuroinflammatory, neurotrophic, and cytotoxic activities, and herein, we report the isolation and structure elucidation of phenolic phytochemicals from the twigs of $C$. sinensis as well as their biological activities.
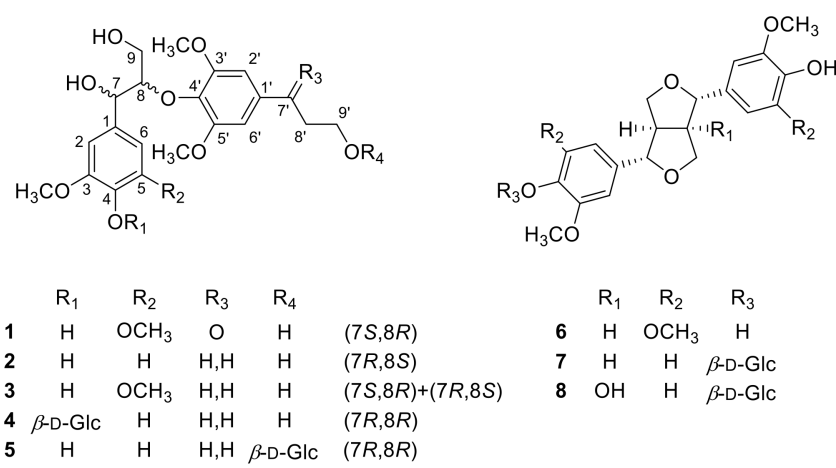

$$
\begin{array}{cccc} 
& \mathrm{R}_{1} & \mathrm{R}_{2} & \mathrm{R}_{3} \\
6 & \mathrm{H} & \mathrm{OCH}_{3} & \mathrm{H} \\
7 & \mathrm{H} & \mathrm{H} & \beta \text {-D-Glc } \\
8 & \mathrm{OH} & \mathrm{H} & \beta \text {-D-Glc }
\end{array}
$$
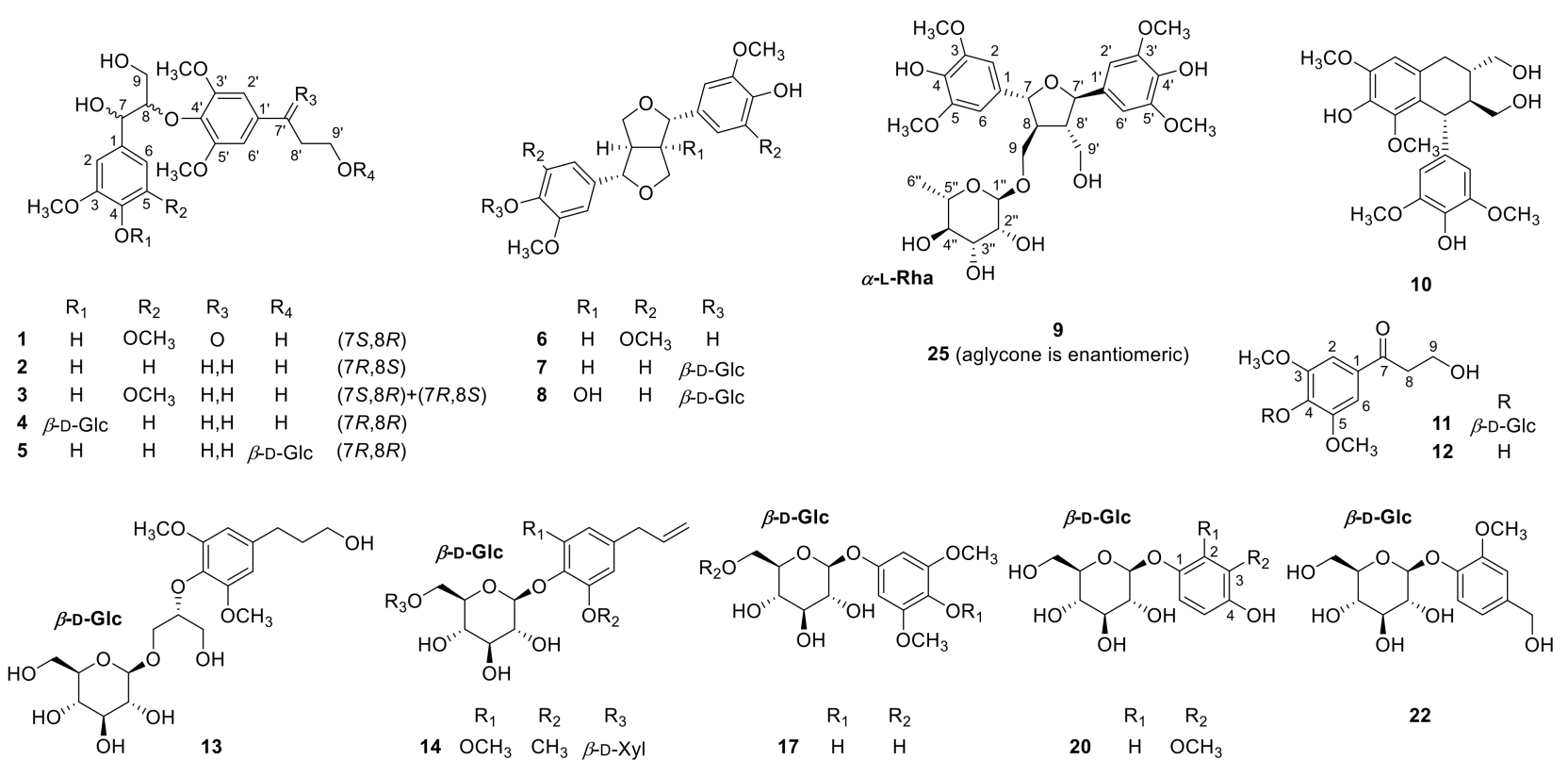

$$
\begin{array}{cccc} 
& \mathrm{R}_{1} & \mathrm{R}_{2} & \mathrm{R}_{3} \\
14 & \mathrm{OCH}_{3} & \mathrm{CH}_{3} & \beta \text {-D-Xyl } \\
15 & \mathrm{H} & \mathrm{H} & \beta \text {-D-Api } \\
16 & \mathrm{H} & \mathrm{CH}_{3} & \beta \text {-D-Api }
\end{array}
$$$$
\begin{array}{ccc} 
& \mathrm{R}_{1} & \mathrm{R}_{2} \\
17 & \mathrm{H} & \mathrm{H} \\
18 & \mathrm{CH}_{3} & \mathrm{H}
\end{array}
$$$$
19 \mathrm{CH}_{3} \beta \text {-D-Api }
$$

$$
\begin{array}{ccc} 
& \mathrm{R}_{1} & \mathrm{R}_{2} \\
\mathbf{2 0} & \mathrm{H} & \mathrm{OCH}_{3} \\
\mathbf{2 1} & \mathrm{OCH}_{3} & \mathrm{H}
\end{array}
$$

22<smiles>OCC1OC(OCC2OC(OCc3ccccc3)[C@H](O)[C@H](O)[C@H]2O)C(O)[C@@H](O)[C@H]1O</smiles>

23<smiles>COc1cc(C(=O)OCC2OC(Oc3ccc(CO)cc3OC)[C@H](O)C(O)[C@H]2O)ccc1O</smiles>

24

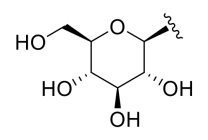

$\beta$-D-GIC



$\alpha$-L-Rha



$\beta$-D-Api

Figure 1. Chemical structure of compounds 1-25. 


\section{Materials and Methods}

\subsection{General Experimental Procedures}

JASCO P-1020 polarimeter equipped with the sodium D line $(590 \mathrm{~nm})$ (JASCO, Easton, MD, USA) was performed to measure specific rotations. Bruker AVANCE III 700 NMR spectrometer at $700 \mathrm{MHz}\left({ }^{1} \mathrm{H}\right)$ and $175 \mathrm{MHz}\left({ }^{13} \mathrm{C}\right)$ was carried out to measure the NMR spectra $\left({ }^{1} \mathrm{H},{ }^{13} \mathrm{C}, \mathrm{COSY}, \mathrm{HSQC}\right.$, and $\left.\mathrm{HMBC}\right)$ at $700 \mathrm{MHz}\left({ }^{1} \mathrm{H}\right)$ and $175 \mathrm{MHz}\left({ }^{13} \mathrm{C}\right)$ with chemical shifts given in ppm $(\delta)$ (Bruker, Karlsruhe, Germany). High-resolution fast atom bombardment mass spectroscopy (HRFABMS) were measured on either a Waters SYNAPT G2 (Milford, MA, USA) or a JEOL JMS700 mass spectrometer (Tokyo, Japan). LC-MS data were measured using an Agilent 1290 Infinity II HPLC instrument (Foster City, CA, USA) coupled to a G6545B quadrupole time-of-flight (Q-TOF) mass spectrometer (Agilent Technologies) with a Kinetex $\mathrm{C}_{18} 5 \mu \mathrm{m}$ column $(250 \mathrm{~mm}$ length $\times 4.6 \mathrm{~mm}$ i.d.; Phenomenex, Torrance, CA, USA). The semipreparative high-performance liquid chromatography (HPLC) furnished with a Gilson 306 pump (Middleton, WI, USA) and a Shodex refractive index detector (New York, NY, USA) was used. Column chromatography was performed employing either silica gel 60 (70-230 and 230-400 mesh; Merck, Darmstadt, Germany) or RP-C 18 silica gel (Merck, 230-400 mesh). Sephadex LH-20 (Pharmacia, Uppsala, Sweden) was utilized for molecular sieve column chromatography. Merck precoated silica gel $\mathrm{F}_{254}$ plates and RP- $\mathrm{C}_{18} \mathrm{~F}_{254 \mathrm{~s}}$ plates (Merck, Darmstadt, Germany) were used for thin-layer chromatography (TLC) analysis. Spots were detected on TLC under UV light or by heating after spraying with anisaldehyde-sulfuric acid.

\subsection{Plant Material}

Twigs of two-year-old C. sinensis $(7.0 \mathrm{~kg})$ were purchased at Yangjae Flower Market in Seoul, Korea, in January 2012. A voucher specimen of the plants (SKKU-NPL 1206) was authenticated by Prof. Kang Ro Lee and deposited in the herbarium of the School of Pharmacy, Sungkyunkwan University, Suwon, Korea.

\subsection{Extraction and Isolation}

Twigs of $C$. sinensis $(7.0 \mathrm{~kg}$ ) were extracted with $80 \%$ aqueous $\mathrm{MeOH}$ (each $10 \mathrm{~L} \times 1$ day, 3 times) under reflux and filtered. The filtrate was evaporated in vacuo to yield a MeOH extract (320 g). The $80 \% \mathrm{MeOH}$ extract was suspended in distilled water and successively partitioned with $n$-hexane ( $3 \mathrm{~g}), \mathrm{CHCl}_{3}(15 \mathrm{~g}), \mathrm{EtOAc}(6 \mathrm{~g})$, and $n$ - $\mathrm{BuOH}$ $(30 \mathrm{~g})$. Repeated column chromatographical fractionation and isolation of $\mathrm{CHCl}_{3}, \mathrm{EtOAc}$, and $n-\mathrm{BuOH}$ soluble layers afforded the compounds 1-24. (See Supplementary Materials for the detailed isolation process).

(7S,8R)-4,7,9,9'-tetrahydroxy-3,5,3',5'-tetramethoxy-7'-oxo-8-O-4'-neolignan (1). Colorless gum; $[\alpha]_{\mathrm{D}}^{25}-12(c 0.1, \mathrm{MeOH}) ; \mathrm{ECD}(\mathrm{MeOH}) \lambda_{\max }(\Delta \varepsilon) 244(-2.3) \mathrm{nm} ;{ }^{1} \mathrm{H}$ and ${ }^{13} \mathrm{C}$ NMR data, see Table 1 ; HRFABMS $m / z 451.1600[\mathrm{M}-\mathrm{H}]^{-}$(calcd for $\mathrm{C}_{22} \mathrm{H}_{27} \mathrm{O}_{10}, 451.1599$ ) (Figures S1-S7).

(7R,8S)-4,7,9,9'-tetrahydroxy-3,3', 5'-trimethoxy-8-O-4'-neolignan (2). Colorless gum; ECD $(\mathrm{MeOH}) \lambda_{\max }(\Delta \varepsilon) 241(+2.1) \mathrm{nm} ;{ }^{1} \mathrm{H}$ and ${ }^{13} \mathrm{C}$ NMR data, see Table 1.

1:1 mixture of (7S,8R)- and (7R,8S)-4,7,9, $9^{\prime}$-tetrahydroxy-3,5,3',5' -tetramethoxy-8-O-4' neolignan (3). Colorless gum; ${ }^{1} \mathrm{H}$ and ${ }^{13} \mathrm{C}$ NMR data, see Table 1.

$7 R, 7^{\prime} R, 8 S, 8^{\prime}$ S-icariol A2 $9^{\prime}-O-\alpha$-L-rhamnopyranoside (9). Colorless gum; $[\alpha]_{D}^{25}+30(c$ 0.1, $\mathrm{MeOH}) ; \mathrm{ECD}(\mathrm{MeOH}) \lambda_{\max }(\Delta \varepsilon) 246(+5.3), 208(-10.1) \mathrm{nm} ;{ }^{1} \mathrm{H}$ and ${ }^{13} \mathrm{C}$ NMR data, see Table 1 ; HRFABMS $m / z 581.2231$ [M - H] ${ }^{-}$(calcd for $\mathrm{C}_{28} \mathrm{H}_{37} \mathrm{O}_{13}$, 581.2229) (Figures S8-S15).

$\beta$-hydroxypropiosyringone $4{ }^{\prime}-O-\beta$-D-glucopyranoside (11). Colorless gum; $[\alpha]_{\mathrm{D}}^{25}+24(c 0.25$, $\mathrm{MeOH}) ;{ }^{1} \mathrm{H}$ and ${ }^{13} \mathrm{C}$ NMR data, see Table 2; HRFABMS $m / z 411.1263$ [M + Na] ${ }^{+}$(calcd for $\mathrm{C}_{17} \mathrm{H}_{24} \mathrm{O}_{10} \mathrm{Na}$, 411.1262) (Figures S16-S22). 
Table 1. ${ }^{1} \mathrm{H}(700 \mathrm{MHz})$ and ${ }^{13} \mathrm{C}(175 \mathrm{MHz})$ NMR data of compounds 1-3, and 9.

\begin{tabular}{|c|c|c|c|c|c|c|c|c|}
\hline \multirow{2}{*}{ Pos. } & \multicolumn{2}{|r|}{$1^{1}$} & \multicolumn{2}{|r|}{$2^{1}$} & \multicolumn{2}{|r|}{$3^{1}$} & \multicolumn{2}{|r|}{$9^{2}$} \\
\hline & $\delta_{C}$ & $\delta_{\mathrm{H}}(\mathrm{multi}, J$ in $\mathrm{Hz})$ & $\delta_{C}$ & $\delta_{\mathrm{H}}(\mathrm{multi}, J$ in $\mathrm{Hz})$ & $\delta_{C}$ & $\delta_{\mathrm{H}}($ multi, $J$ in $\mathrm{Hz})$ & $\delta_{C}$ & $\delta_{H}($ multi, $J$ in $\mathrm{Hz})$ \\
\hline 1 & 130.3 & & & & 130.6 & & 134.3 & \\
\hline 2 & 102.7 & $6.58(\mathrm{~s})$ & & $6.97(d, 1.6)$ & 102.6 & $6.59(\mathrm{~s})$ & 105.1 & $6.75(\mathrm{~s})$ \\
\hline 3 & 147.2 & & & & 147.2 & & 149.5 & \\
\hline 4 & 134.2 & & & & 134.0 & & 136.4 & \\
\hline 5 & 147.2 & & & $6.86(\mathrm{~d}, 8.1)$ & 147.2 & & 149.5 & \\
\hline 6 & 102.7 & $6.58(\mathrm{~s})$ & & $6.75(\mathrm{dd}, 8.1,1.6)$ & 102.6 & $6.59(\mathrm{~s})$ & 105.1 & $6.75(\mathrm{~s})$ \\
\hline 7 & 73.1 & 4.99 (brs) & 72.6 & $5.00(\mathrm{~d}, 3.5)$ & 72.7 & $4.99(\mathrm{~d}, 3.2)$ & 85.2 & $5.03(\mathrm{~d}, 8.4)$ \\
\hline 8 & 87.5 & $4.23(\mathrm{ddd}, 6.6,3.5,3.0)$ & 87.2 & $4.11(\mathrm{dt}, 6.7,2.9)$ & 87.2 & $4.10(\mathrm{dt}, 6.8,3.1)$ & 51.8 & $2.51(\mathrm{~m})$ \\
\hline $9 a$ & 60.7 & 3.93 (overlap) & 60.8 & 3.87 (overlap) & 60.8 & 3.87 (overlap) & 67.8 & $3.82(\mathrm{~m})$ \\
\hline $9 b$ & & $3.54(\mathrm{~m})$ & & 3.48 (overlap) & & $3.46(\mathrm{~m})$ & & $3.57(\mathrm{dd}, 9.9,4.9)$ \\
\hline $1^{\prime}$ & 133.1 & & 133.1 & & 133.1 & & 134.7 & \\
\hline $2^{\prime} / 6^{\prime}$ & 105.6 & $7.29(\mathrm{~s})$ & 105.5 & $6.48(\mathrm{~s})$ & 105.5 & $6.49(\mathrm{~s})$ & 104.8 & $6.76(\mathrm{~s})$ \\
\hline $3^{\prime} / 5^{\prime}$ & 153.6 & & 153.3 & & 153.3 & & 149.5 & \\
\hline $4^{\prime}$ & 139.9 & & 138.8 & & 138.9 & & 136.3 & \\
\hline $7^{\prime}$ & 199.1 & & 34.4 & $2.70(\mathrm{~m})$ & 34.4 & $2.71(\mathrm{~m})$ & 84.5 & $5.06(\mathrm{~d}, 8.4)$ \\
\hline $8^{\prime}$ & 40.4 & $3.23(t, 5.4)$ & 32.8 & $1.91(\mathrm{~m})$ & 32.8 & $1.92(\mathrm{~m})$ & 54.6 & $2.38(\mathrm{~m})$ \\
\hline $9^{\prime} \mathrm{a}$ & 58.3 & $4.06(t, 5.3)$ & 62.3 & $3.71(t, 6.3)$ & 62.3 & $3.72(t, 6.3)$ & 61.6 & $3.78(\mathrm{dd}, 11.2,5.2)$ \\
\hline $9^{\prime} b$ & & & & & & & & $3.69(\mathrm{dd}, 11.2,4.4)$ \\
\hline $1^{\prime \prime}$ & & & & & & & 102.3 & $4.70(\mathrm{~d}, 1.3)$ \\
\hline $2^{\prime \prime}$ & & & & & & & 72.3 & $3.81(\mathrm{~m})$ \\
\hline $3^{\prime \prime}$ & & & & & & & 72.7 & $3.65(\mathrm{dd}, 4.5,3.2)$ \\
\hline $4^{\prime \prime}$ & & & & & & & 74.1 & $3.40(\mathrm{~m})$ \\
\hline $5^{\prime \prime}$ & & & & & & & 70.3 & $3.61(\mathrm{dq}, 9.5,6.5)$ \\
\hline $6^{\prime \prime}$ & & & & & & & 18.2 & $1.27(\mathrm{~d}, 6.5)$ \\
\hline$\stackrel{3-}{\mathrm{OCH}_{3}}$ & 56.5 & $3.88(\mathrm{~s})$ & 56.1 & $3.90(\mathrm{~s})$ & 56.5 & $3.88(\mathrm{~s})$ & 57.0 & $3.90(\mathrm{~s})$ \\
\hline $\begin{array}{c}5- \\
\mathrm{OCH}_{3}\end{array}$ & 56.5 & $3.88(\mathrm{~s})$ & & & 56.5 & $3.88(\mathrm{~s})$ & 57.0 & $3.90(\mathrm{~s})$ \\
\hline $\begin{array}{c}3^{\prime}, 5^{\prime}- \\
\mathrm{OCH}_{3}\end{array}$ & 56.6 & $3.96(\mathrm{~s})$ & 56.3 & $3.87(\mathrm{~s})$ & 56.3 & $3.88(\mathrm{~s})$ & 57.0 & $3.90(\mathrm{~s})$ \\
\hline $4-\mathrm{OH}$ & & $5.47(\mathrm{~s})$ & & $5.55(\mathrm{~s})$ & & $5.45(\mathrm{~s})$ & & \\
\hline
\end{tabular}

${ }^{1}$ Measured in chloroform- $d ;{ }^{2}$ Measured in methanol- $d_{4}$.

Table 2. ${ }^{1} \mathrm{H}(700 \mathrm{MHz})$ and ${ }^{13} \mathrm{C}(175 \mathrm{MHz})$ NMR data of compound 11 in methanol- $d_{4}$.

\begin{tabular}{ccc}
\hline & \multicolumn{2}{c}{$\mathbf{1}^{\mathbf{1}}$} \\
\cline { 2 - 3 } Pos. & $\boldsymbol{\delta}_{\mathbf{C}}$ & $\boldsymbol{\delta}_{\mathbf{H}}$ (multi, $\boldsymbol{J}$ in $\left.\mathbf{H z}\right)$ \\
\hline 1 & 134.6 & \\
$2 / 6$ & 107.6 & $7.23(\mathrm{~s})$ \\
$3 / 5$ & 154.4 & \\
4 & 140.7 & \\
7 & 200.0 & $3.11(\mathrm{t}, 6.1)$ \\
8 & 42.1 & $3.86(\mathrm{t}, 6.1)$ \\
9 & 58.8 & $5.00(\mathrm{~d}, 7.5)$ \\
$1^{\prime}$ & 104.6 & $3.40(\mathrm{dd}, 8.8,7.5)$ \\
$2^{\prime}$ & 75.9 & $3.33(\mathrm{t}, 8.8)$ \\
$3^{\prime}$ & 78.0 & $3.30(\mathrm{t}, 8.8)$ \\
$4^{\prime}$ & 71.5 & $3.12(\mathrm{ddd}, 8.8,5.3,2.3)$ \\
$5^{\prime}$ & 78.6 & $3.67(\mathrm{dd}, 11.9,2.3)$ \\
$6^{\prime} \mathrm{a}$ & 62.7 & $3.55(\mathrm{dd}, 11.9,5.3)$ \\
$6^{\prime} \mathrm{b}$ & & $3.81(\mathrm{~s})$ \\
$3^{\prime} 5-\mathrm{OCH} 3$ & 57.3 &
\end{tabular}




\section{4. ${ }^{1} \mathrm{H}$ NMR Simulation for H-7 of Compound 1}

MestReNova Version 14.1.2-25024 was used to simulate the H-7 peak. The "Spin Simulation" under the "Prediction" tab was clicked to open the dialog box. The "Spin Groups" was set to be "2" (default value), the "Shifts (ppm)" values of "A" and "B" were given "4.987" and "4.232", respectively, with the "Line Width $(\mathrm{Hz})$ " of both "3.0". After the coupling constant between " $\mathrm{A}$ " and "B" was set as "3.5" or "6.7", the icon with "New Simulation" at the top left was clicked to generate the simulated ${ }^{1} \mathrm{H}$ NMR peaks of H-7 and $\mathrm{H}-8$ of $\mathbf{1}$.

\subsection{Acid Hydrolysis of Compounds $\mathbf{6}$ and $\mathbf{1 1}$ and Sugar Analysis}

The sugar analysis experiment was performed as described in previous communication by Tanaka et al. with some modifications [17]. Compounds $\mathbf{9}$ and $\mathbf{1 1}$ (each of $0.5 \mathrm{mg}$ ) were individually hydrolyzed with $1 \mathrm{~N} \mathrm{HCl}(1.0 \mathrm{~mL})$ for $2 \mathrm{~h}$ at $100^{\circ} \mathrm{C}$. Each hydrolysate was extracted using $\mathrm{CHCl}_{3}$, and then the aqueous layers were evaporated to remove the $\mathrm{HCl}$ and to afford sugar from each hydrolysate. Each $\mathrm{H}_{2} \mathrm{O}$-soluble fraction was added to anhydrous pyridine $(400 \mu \mathrm{L})$ containing L-cysteine methyl ester hydrochloride $(1.1 \mathrm{mg})$, which were heated at $60^{\circ} \mathrm{C}$ for $1 \mathrm{~h}$. Then, $O$-tolyl isothiocyanate $(30 \mu \mathrm{L})$ was added to the reaction mixture and heated at $60^{\circ} \mathrm{C}$ for another $1 \mathrm{~h}$. After the reaction, each reaction mixture was analyzed by LC-MS $\left(0.7 \mathrm{~mL} / \mathrm{min} ; 25 \%\right.$ aqueous $\mathrm{CH}_{3} \mathrm{CN}$ with $0.1 \%$ formic acid for $40 \mathrm{~min}$ ). The authentic samples of L-rhamnopyranose and D-glucopyranose were derivatized and analyzed by the same method mentioned above, and these monosaccharides were also derivatized with D-cysteine methyl ester hydrochloride instead of its L-form to prepare their enantiomeric derivatives. The hydrolysate derivatives of 9 and 11 were $25.4 \mathrm{~min}$ (L-rhamnopyranose) and $14.9 \mathrm{~min}$ (D-glucopyranose) which matched well with those of authentic L-rhamnopyranose $(25.3 \mathrm{~min}$ ) and D-glucopyranose (14.9 $\mathrm{min})$, respectively, rather than their enantiomeric derivatives (13.2 min (D-rhamnopyranose) and 13.7 min (L-glucopyranose)) (Figures S15 and S22).

\subsection{NO Production Assays}

Analogous as described in [18]. The BV-2 cells, developed by Dr. V. Bocchini at the University of Perugia (Perugia, Italy), were used for this study $[19,20]$. The cells were seeded in a 96-well plate $\left(4 \times 10^{4}\right.$ cells/well $)$ and incubated in the presence or absence of various doses of tested compounds (1-24). Lipopolysaccharide (LPS) $(100 \mathrm{ng} / \mathrm{mL})$ was added to all the pre-treated wells except the control one and grown for $1 \mathrm{~d}$. The produced levels of nitrite $\left(\mathrm{NO}_{2}\right)$, a soluble oxidized product of $\mathrm{NO}$, was evaluated with $0.1 \% \mathrm{~N}-1$ napthylethylenediamine dihydrochloride and $1 \%$ sulfanilamide in $5 \%$ phosphoric acid, aka the Griess reagent. The supernatant $(50 \mu \mathrm{L})$ was mixed with the Griess reagent $(50 \mu \mathrm{L})$. After $10 \mathrm{~min}$ the absorbance was gauged at $570 \mathrm{~nm}$. For a positive control, the reported nitric oxide synthase (NOS) inhibitor $N^{\mathrm{G}}$-monomethyl-L-arginine (L-NMMA) was employed. Graded sodium nitrite solution was utilized to determine nitrite concentrations. A 3-[4,5dimethylthiazol-2-yl]-2,5-diphenyltetrazolium bromide (MTT) assay was used for the cell viability assay.

\subsection{Assays for Nerve Growth Factor NGF Release from C6 Cells}

Analogous as described in [21]. C6 glioma cell lines were used to measure the nerve growth factor (NGF) of the culture medium, which were fixed with $10 \%$ fetal bovine serum (FBS) and 1\% penicillin-streptomycin (PS) in an incubator filled with $5 \% \mathrm{CO}_{2}$. The cells were seeded in a 24-well culture plate $\left(1 \times 10^{5}\right.$ cells /well $)$ and incubated for $24 \mathrm{~h}$. The cells were treated with or without $20 \mu \mathrm{M}$ of the compounds (1-24), together with serum-free Dulbecco's modified Eagle's medium (DMEM) for another $24 \mathrm{~h}$. Released NGF levels from the supernatants from each cell were measured using an ELISA development kit (R\&D System, Minneapolis, MN, USA). Besides, the cell viability was evaluated by 3[4,5-dimethylthiazol-2-yl]-2,5-diphenyltetrazolium bromide (MTT) assay by comparison 
with 6-shogaol as a positive control and the results are expressed as percentage of the control group.

\subsection{Cytotoxicity Assessment}

The cytotoxicity of purified compounds (1-24) were tested against the A-549 (nonsmall cell lung adenocarcinoma), SK-OV-3 (ovary malignant ascites), SK-MEL-2 (skin melanoma), and MKN-1 (adenosquamous carcinoma), utilizing the sulforhodamine B colorimetric (SRB) method [22]. Cisplatin ( $\geq 98 \%$; Sigma-Aldrich) served as a positive control.

\section{Results and Discussion}

\subsection{Structure Elucidation of Compounds 1-24}

Compound 1 was purified as a colorless gum and its molecular formula was determined as $\mathrm{C}_{22} \mathrm{H}_{28} \mathrm{O}_{10}$ according to the deprotonated molecular ion at $\mathrm{m} / \mathrm{z}$ at $451.1600[\mathrm{M}-$ $\mathrm{H}]^{-}$in the HRFABMS data (calcd. for $\left.\mathrm{C}_{22} \mathrm{H}_{27} \mathrm{O}_{10}, 451.1599\right)$. Analysis of the ${ }^{1} \mathrm{H}$ NMR spectrum of 1 indicated the presence of two 1,3,4,5-tetrasubstituted benzene rings $\left(\delta_{\mathrm{H}} 7.29(2 \mathrm{H}\right.$, s, $\left.\mathrm{H}-2^{\prime}, 6^{\prime}\right)$ and $\left.6.58(2 \mathrm{H}, \mathrm{s}, \mathrm{H}-2,6)\right)$, two oxygenated methines $\left(\delta_{\mathrm{H}} 4.99(1 \mathrm{H}, \mathrm{brs}, \mathrm{H}-7)\right.$ and 4.23 $(1 \mathrm{H}, \mathrm{ddd}, J=6.6,3.5,3.0 \mathrm{~Hz}, \mathrm{H}-8))$, two oxygenated methylenes $\left(\delta_{\mathrm{H}} 4.06(2 \mathrm{H}, \mathrm{t}, J=5.3 \mathrm{~Hz}\right.$, $\left.\mathrm{H}^{\prime} 9^{\prime}\right), 3.93(1 \mathrm{H}$, overlap, H-9a), and $3.54(1 \mathrm{H}, \mathrm{m}, \mathrm{H}-9 \mathrm{~b}))$, a methylene $\left(\delta_{\mathrm{H}} 3.23(2 \mathrm{H}, \mathrm{t}\right.$, $\left.\left.J=5.4 \mathrm{~Hz}, \mathrm{H}-8^{\prime}\right)\right)$, and four methoxy groups $\left(\delta_{\mathrm{H}} 3.96\left(6 \mathrm{H}, \mathrm{s}, 3^{\prime}, 5^{\prime}-\mathrm{OCH}_{3}\right)\right.$ and $3.88(6 \mathrm{H}, \mathrm{s}, 3,5-$ $\left.\mathrm{OCH}_{3}\right)$ ). The ${ }^{13} \mathrm{C}$ spectrum of 1 showed 22 carbon signals for two 1,3,4,5-tetrasubstituted benzene rings $\left(\delta_{\mathrm{C}} 153.6(\times 2), 147.2(\times 2), 139.9,134.2,133.1,130.3,105.6(\times 2)\right.$, and 102.5 $(\times 2))$, a carbonyl carbon $\left(\delta_{C} 199.1\right)$, four methoxy carbons $\left(\delta_{C} 56.6(\times 2)\right.$ and $\left.56.5(\times 2)\right)$, four oxygenated carbons $\left(\delta_{C} 87.5,73.1,60.7\right.$, and 58.3), and a methylene carbon $\left(\delta_{C} 40.4\right)$. These NMR spectra of 1 were similar to those of 3 (Table 1) [23], except for the presence of the carbonyl carbon signal at $\delta_{\mathrm{C}} 199.1\left(\mathrm{C}-7^{\prime}\right)$ in 1 rather than the methylene carbon signal at $\delta_{\mathrm{C}} 34.4\left(\mathrm{C}-7^{\prime}\right)$ in 3 . The HMBC correlations from $\mathrm{H}-2^{\prime}, 6^{\prime} / \mathrm{H}-8^{\prime} / \mathrm{H}-9^{\prime}$ to $\mathrm{C}-7^{\prime}$ were observed, suggesting that carbonyl carbon is located at C-7'. The planar structure of $\mathbf{1}$ was established through 2D NMR spectra analysis including COSY, HSQC, and HMBC spectra (Figure 2A). In 8-O-4'-oxyneolignan derivatives, the relatively small $(\sim 4 \mathrm{~Hz})$ and large $(\sim 8 \mathrm{~Hz})$ coupling constants between $\mathrm{H}-7$ and H-8 indicate erythro- or threo-configuration, respectively, in chloroform- $d$ [24-26]. When the $\mathrm{H}-7$ peak was analyzed to measure the ${ }^{3} J_{\mathrm{H}-7, \mathrm{H}-8}$ value, however, its shape was found to be a broad singlet. Alternatively, the H-8 peak showed the splitting pattern of doublet of doublet of doublet (ddd) with coupling constants of 6.7, 3.5, and $3.0 \mathrm{~Hz}$. In order to deduce the ${ }^{3} \mathrm{~J}_{\mathrm{H}-7, \mathrm{H}-8}$ value among them, the $\mathrm{H}-7$ peak was simulated with coupling constants of 3.5 and $6.7 \mathrm{~Hz}$. As shown in Figure 2B (middle) the simulated peak with the $3.5 \mathrm{~Hz}$ coupling constant was more similar to that of experimental peak rather than that with $6.7 \mathrm{~Hz}$ coupling constant. Therefore, the ${ }^{3} J_{\mathrm{H}-7, \mathrm{H}-8}$ value was assigned as 3.0 or $3.5 \mathrm{~Hz}$ which suggested erythro-form. The difference of ${ }^{13} \mathrm{C}$ NMR chemical shift between C-7 and C- 8 can be also used for its relative configuration assignment. The $\Delta \delta_{C-8, C-7}$ value was $\sim 14.6 \mathrm{ppm}$ in the erythro-form whereas $\sim 15.5 \mathrm{ppm}$ was observed in the threo-form [24]. By observing $14.4 \mathrm{ppm}$ of $\Delta \delta_{\mathrm{C}-8, \mathrm{C}-7}$ value in the ${ }^{13} \mathrm{C}$ NMR data of $\mathbf{1}$ (Figure $2 \mathrm{C}$ ), the relative configuration between C-7 and C-8 was deduced as erythro-form. The $8 R$ configuration of 1 was confirmed by means of analysis of its ECD spectrum displaying a characteristic negative Cotton effect at $244 \mathrm{~nm}$ (Figure 2D) [26,27]. Thus, the structure of 1 was established as

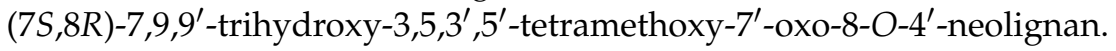


A

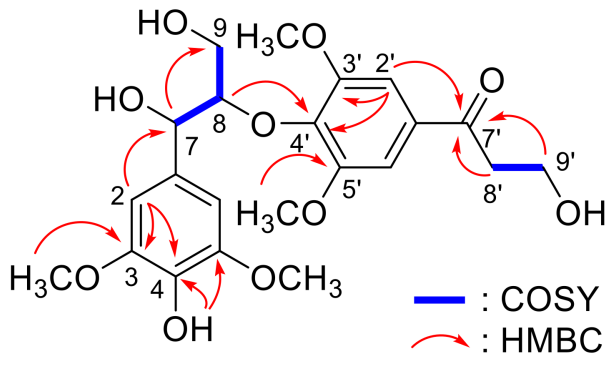

C

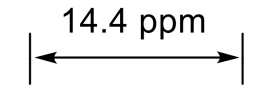

C-8 C-7

$\Delta \delta_{\mathrm{C} 8-\mathrm{C} 7}$

erythro: $14.6 \mathrm{ppm}$

threo: $15.5 \mathrm{ppm}$

(reference \#23)
B

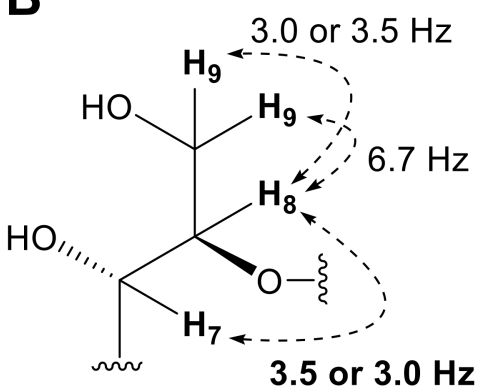

1
Experimental $\mathrm{H}-7$ (brs)

Simulated $(\mathrm{d}, 3.5 \mathrm{~Hz})$

Simulated $(\mathrm{d}, 6.7 \mathrm{~Hz})$



Experimental $\mathrm{H}-8$

[ddd $(6.7,3.5,3.0 \mathrm{~Hz})$ ]

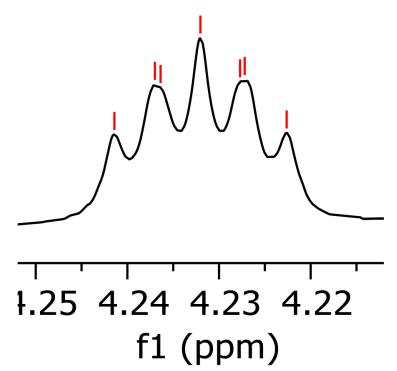

D

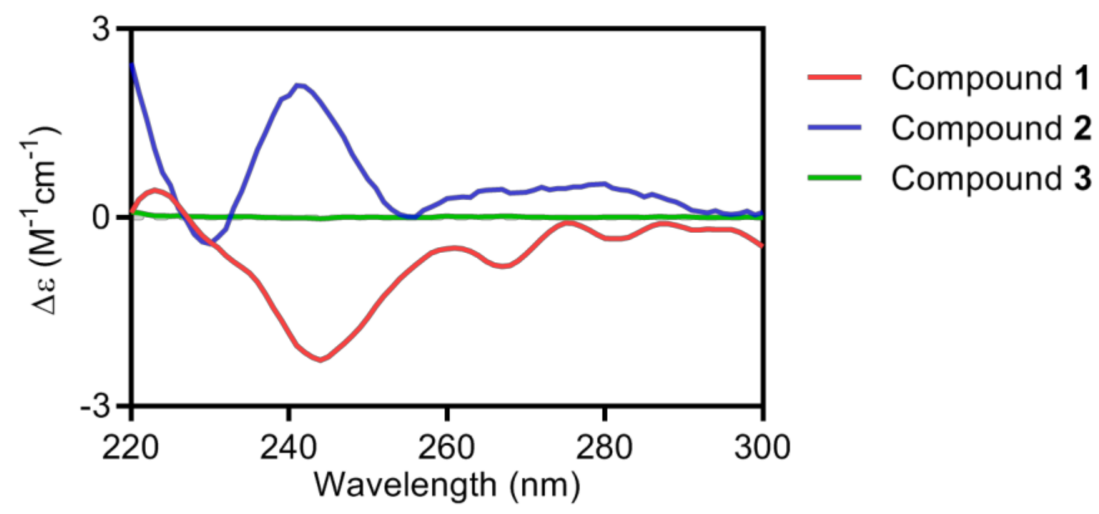

Figure 2. Structure elucidation of 1-3. (A) Key COSY and HMBC correlations of 1. (B) Coupling constants values among $\mathrm{H}-7, \mathrm{H}-8$, and H-9 (left) deduced by analysis of ${ }^{1} \mathrm{H}$ NMR peaks of $\mathrm{H}-7$ (middle) and H-8 (right). (C) Zoomed-in ${ }^{13} \mathrm{C} \mathrm{NMR}$ spectra of 1 for C-7 and C-8. (D) ECD spectra of 1-3. The negative or positive Cotton effect around 240-245 nm indicated the $8 R$ - or $8 S$-configuration, respectively.

Compounds 2 and 3 were previously reported from Bursera tonkinensis [23], and Epimedium sagittatum [28] and Fraxinus mandshurica [29], respectively, without determination of the absolute configuration of C-7 and C-8 (Figure S23-S26). The relative configuration between C-7 and C-8 were assigned as erythro by the same empirical rule applied for 1; the relatively small ${ }^{3} J_{\mathrm{H}-7, \mathrm{H}-8}$ value was observed from both $2(3.5 \mathrm{~Hz})$ and 3 $(3.2 \mathrm{~Hz})$ (Table 1). A positive Cotton effect at $241 \mathrm{~nm}$ from ECD spectrum of 2 indicated an $8 S$ configuration of 2 and the absence of any characteristic Cotton effect from the ECD spectrum of $\mathbf{3}$, suggesting 3 as a racemic mixture (Figure 2D).

Compound 9 was isolated as a colorless gum with a molecular formula of $\mathrm{C}_{28} \mathrm{H}_{38} \mathrm{O}_{13}$. The ${ }^{1} \mathrm{H}$ NMR spectrum of 9 showed two 1,3,4,5-tetrasubstituted benzene rings $\left(\delta_{\mathrm{H}} 6.76(2 \mathrm{H}\right.$, $\left.\mathrm{s}, \mathrm{H}-2^{\prime}, 6^{\prime}\right)$ and $\left.6.75(2 \mathrm{H}, \mathrm{s}, \mathrm{H}-2,6)\right)$, two oxygenated methines $\left(\delta_{\mathrm{H}} 5.06(1 \mathrm{H}, \mathrm{d}, J=8.4 \mathrm{~Hz}\right.$, 
$\left.\mathrm{H}-7^{\prime}\right)$ and $\left.5.03(1 \mathrm{H}, \mathrm{d}, J=8.4 \mathrm{~Hz}, \mathrm{H}-7)\right)$, two oxygenated methylenes $\left(\delta_{\mathrm{H}} 3.82(1 \mathrm{H}, \mathrm{m}\right.$, H-9a), $3.78\left(1 \mathrm{H}, \mathrm{dd}, J=11.2,5.2 \mathrm{~Hz}, \mathrm{H}-9^{\prime} \mathrm{a}\right), 3.69\left(1 \mathrm{H}, \mathrm{dd}, J=11.2,4.4 \mathrm{~Hz}, \mathrm{H}-9^{\prime} \mathrm{b}\right)$, and $\left.3.57\left(1 \mathrm{H}, \mathrm{dd}, J=9.9,4.9 \mathrm{~Hz}, \mathrm{H}-9^{\prime} \mathrm{b}\right)\right)$, two methines $(2.51(1 \mathrm{H}, \mathrm{m}, \mathrm{H}-8)$ and $2.38(1 \mathrm{H}, \mathrm{m}$, $\left.\left.\mathrm{H}-8^{\prime}\right)\right)$, four methoxy groups $\left(\delta_{\mathrm{H}} 3.90\left(12 \mathrm{H}, \mathrm{s}, 3,5,3^{\prime}, 5^{\prime}-\mathrm{OCH}_{3}\right)\right)$, and an $\alpha$-rhamnopyranosyl unit $\left(\delta_{\mathrm{H}} 4.70\left(1 \mathrm{H}, \mathrm{d}, J=1.3 \mathrm{~Hz}, \mathrm{H}--^{\prime \prime}\right), 3.81\left(1 \mathrm{H}, \mathrm{m}, \mathrm{H}-2^{\prime \prime}\right), 3.65(1 \mathrm{H}, \mathrm{dd}, J=4.5,3.2 \mathrm{~Hz}\right.$, $\left.\mathrm{H}-3^{\prime \prime}\right), 3.61\left(1 \mathrm{H}, \mathrm{dq}, J=9.5,6.5 \mathrm{~Hz}, \mathrm{H}-5^{\prime \prime}\right), 3.40\left(1 \mathrm{H}, \mathrm{m}, \mathrm{H}-4^{\prime \prime}\right)$, and $1.27(3 \mathrm{H}, \mathrm{d}, J=6.5 \mathrm{~Hz}$, $\left.\left.\mathrm{H}-6^{\prime \prime}\right)\right)$. The ${ }^{13} \mathrm{C}$ NMR spectrum of 2 revealed 28 resonances, comprising 12 benzene ring carbons $\left[\delta_{\mathrm{C}} 149.5(\times 4), 136.4,136.3,134.7,134.3,105.1(\times 2)\right.$, and $\left.104.8(\times 2)\right]$, four methoxy carbons $\left(\delta_{\mathrm{C}} 57.0(\times 4)\right)$, four oxygenated carbons $\left(\delta_{\mathrm{C}} 85.2,84.5,67.8\right.$, and 61.6$)$, two methine carbons $\left(\delta_{\mathrm{C}} 54.6\right.$ and 51.8$)$, and a rhamnopyranosyl unit $\left(\delta_{\mathrm{C}} 102.3,74.1,72.7,72.3,70.3\right.$, and 18.2). These spectroscopic data were almost identical with those of $7 S, 7^{\prime} S, 8 R, 8^{\prime} R$-icariol A2 9'-O- $\alpha$-L-rhamnopyranoside (25) [30]. Intensive 2D NMR data analysis (Figure 3A) confirmed that 9 and $\mathbf{2 5}$ have the same the planar structures. The absolute configuration of the known compound 25 was determined as $7 S, 7^{\prime} S, 8 R, 8^{\prime} R$ by observing the negative Cotton effect around 240-250 nm in the ECD spectrum (Figure S9) [30], however, the new compound 9 showed the positive Cotton effect around that area (246 nm, Figure 3B), indicating $7 R, 7^{\prime} R, 8 S, 8^{\prime} S$-configuration. In addition, the opposite sign of the specific rotation values of $9,[\alpha]_{\mathrm{D}}^{25}+30(c 0.1, \mathrm{MeOH})$, and $25,[\alpha]_{\mathrm{D}}^{25}-51.4(c 0.1, \mathrm{MeOH})[30]$, supported the initial assignment. Finally, the L-form of rhamnopyranosyl moiety was assigned by LCMS analysis on the chiral derivatized monosaccharide obtained by hydrolysis of 9 and following chemical reaction [17]. The retention time of derivatized rhamnopyranose (25.4 $\mathrm{min}$ ) was matched with that of standard L-rhamnopyranose $(25.3 \mathrm{~min})$ rather than D-rhamnopyranose (13.2 $\mathrm{min}$ ) (Figure 2C). Thus, the structure of 9 was determined as $7 R, 7^{\prime} R, 8 S, 8^{\prime} S$-icariol A2 $9^{\prime}-O-\alpha$-L-rhamnopyranoside.

A

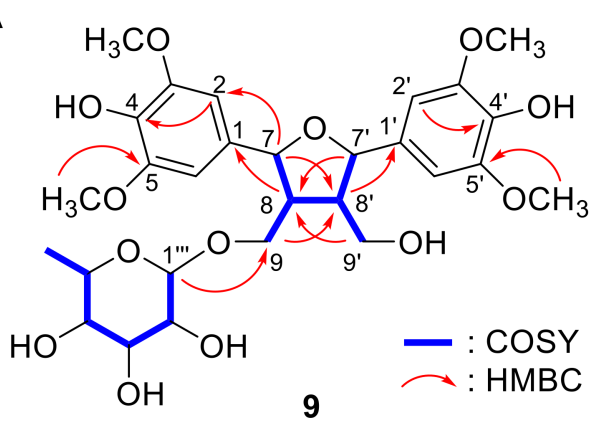

B

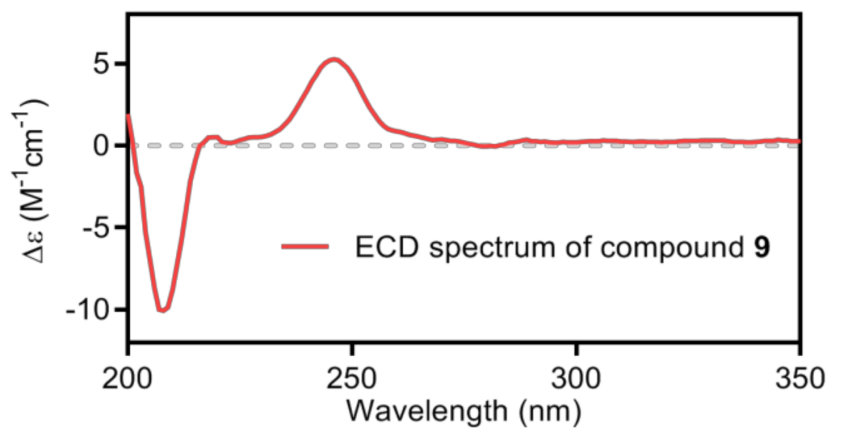

Figure 3. Structure elucidation of 9. (A) Key COSY and HMBC correlations of 9. (B) Extracted ion chromatograms (EICs, $m / z$ 431.1311) of chiral derivatized L- and D-rhamnopyranose purchased or obtained by hydrolysis of 9 . (C) ECD spectrum of 9 . The positive Cotton effect at $246 \mathrm{~nm}$ indicated the $7 R, 7^{\prime} R, 8 S, 8^{\prime} S$-configuration.

Compound 11 was obtained as a colorless gum, and its molecular formula was deduced as $\mathrm{C}_{17} \mathrm{H}_{24} \mathrm{O}_{10}$ based upon the HRFABMS data. The ${ }^{1} \mathrm{H}$ and ${ }^{13} \mathrm{C}$ NMR spectra of $\mathbf{1 1}$ 
were comparable to those of 3-hydroxyl-1-(4-hydroxy-3,5-dimethoxyphenyl)-1-propanone (or $\beta$-hydroxypropiosyringone, 12) [31], except for the presence of resonances for a $\beta$ glucopyranosyl unit $\left(\delta_{\mathrm{H}} 5.00\left(1 \mathrm{H}, \mathrm{d}, J=7.5 \mathrm{~Hz}, \mathrm{H}-1^{\prime}\right), 3.67\left(1 \mathrm{H}, \mathrm{dd}, J=11.9,2.3 \mathrm{~Hz}, \mathrm{H}-6^{\prime} \mathrm{a}\right)\right.$, $3.55\left(1 \mathrm{H}, \mathrm{dd}, J=11.9,5.3 \mathrm{~Hz}, \mathrm{H}-6^{\prime} \mathrm{b}\right), 3.40\left(1 \mathrm{H}, \mathrm{dd}, J=8.8,7.5 \mathrm{~Hz}, \mathrm{H}-2^{\prime}\right), 3.33(1 \mathrm{H}, \mathrm{t}$, $\left.J=8.8 \mathrm{~Hz}, \mathrm{H}-3^{\prime}\right), 3.30\left(1 \mathrm{H}, \mathrm{t}, J=8.8 \mathrm{~Hz}, \mathrm{H}-4^{\prime}\right), 3.12\left(1 \mathrm{H}, \mathrm{ddd}, J=8.8,5.3,2.3 \mathrm{~Hz}, \mathrm{H}-5^{\prime}\right)$; $\delta_{\mathrm{C}} 104.6,78.6,78.0,75.9,71.5$, and 62.7). On the basis of the HMBC cross peak of H-1 ${ }^{\prime}$ with $\mathrm{C}-4$, the location of the $\beta$-glucopyranosyl unit was confirmed to be connected at C-4 by an ether bond (Figure 4A). Acid hydrolysis of $\mathbf{1 1}$ afforded glucopyranose, which was identified as D-form by the same method as described above (Figure 4B). Thus, the structure of $\mathbf{1 1}$ was elucidated as $\beta$-hydroxypropiosyringone $4^{\prime}-O-\beta$-D-glucopyranoside.

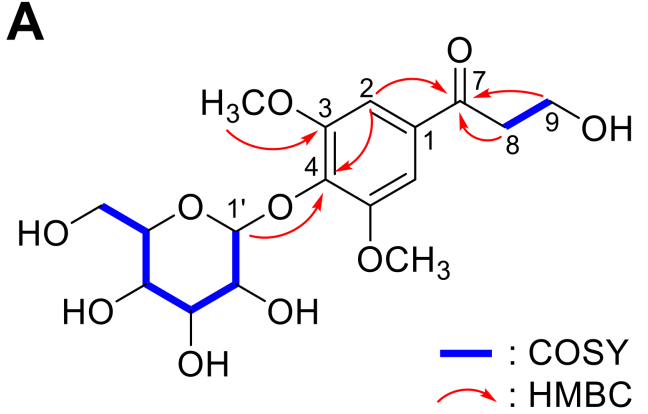

11
B

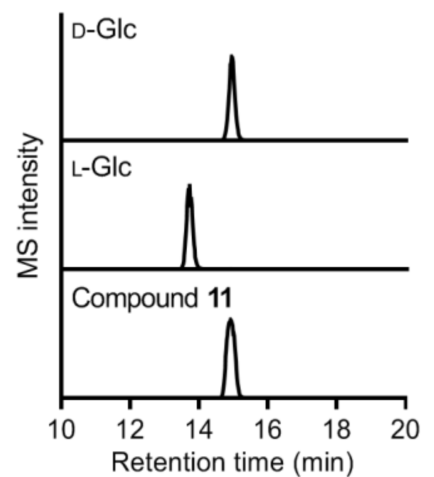

Figure 4. Structure elucidation of 11. (A) Key COSY and HMBC correlations of 11. (B) Extracted ion chromatograms (EICs, $m / z$ 447.1260) of chiral derivatized D- and L-glucopyranose purchased or obtained by hydrolysis of $\mathbf{1 1}$.

The other known compounds were identified as (7S,8R)-1-[4-(O- $\beta$-D-glucopyranosyl)-3methoxyphenyl]-2-[4-(3-hydroxypropyl)-2,6-dimethoxyphenoxyl]-1,3-propanediol (4) [32], 3-[4-[(1R,2S)-2-hydroxy-2-(4-hydroxy-3-methoxyphenyl)-1-(hydroxymethyl)ethoxy]-3-methoxyphenyl]propyl $\beta$-D-glucopyranoside (5) [27], syringatesinol (6) [33], pinoresinol-4-Oglucoside (7) [34], 8-hydroxypinoresinol-4'-O- $\beta$-D-glucose (8) [35], (-)-lyoniresinol $3 \alpha-O-\beta$ D-glucopyranoside (10) [36], 3-hydroxyl-1-(4-hydroxy-3,5-dimethoxyphenyl)-1-propanone (12) [31], (2R)-O-[4'-(3'-hydroxypropyl)-2', 6'-dimethoxyphenyl]-3-O- $\beta$-D-glucopyranosylsn-glycerol (13) [37], 4-allyl-2,6-dimethoxyphenyl 1-O- $\beta$-D-xylopyranosyl-( $1 \rightarrow 6)-\beta$-D-glucopyranoside (14) [38], 4-allyl-2-hydroxyphenyl 1-O- $\beta$-D-apiosyl-(1 $\rightarrow 6)-\beta$-D-glucoside (15) [39], 4 -allyl-2-methoxyphenyl 6-O- $\beta$-D-apiosyl-( $1 \rightarrow 6)-\beta$-D-glucoside (16) [40], 3,5-dimethoxy1-hydroxy-4-O- $\beta$-D-glucoside (17) [41], 3,4,5-trimethoxyphenol 1-O- $\beta$-D-glucopyranoside (18) [42], 3,4,5-trimethoxyphenyl 1-O- $\beta$-D-apiofuranosyl- $\left(1^{\prime \prime} \rightarrow 6^{\prime}\right)-\beta$-D-glucoside (19) [43], tachioside (20), isotachioside (21) [44], vanillyl alcohol-4-O- $\beta$-D-glucopyranoside (22) [45], benzyl $\beta$-D-xylopyranosyl-(1 $\rightarrow 6)$ - $\beta$-D-glucopyranoside (23) [46], and 4-hydroxy-2,6-dimethoxyphenyl 6'-O-vanilloyl- $\beta$-D-glucopyranoside (24) [47] by comparing their spectroscopic data with reported data.

\subsection{Anti-Neuroinflammatory Activity of the Isolated Compounds (1-24)}

Alzheimer's disease, a neurodegenerative disease, is an unsolved social and medical problem and is strongly associated with neurotrophins (e.g., NGF, brain-derived neurotrophic factor (BDNF), neurotrohpin-3 (NT-3), and NT-4/5) and neuroinflammatory mediators (e.g., nitric oxide (NO), tumor necrosis factor alpha (TNF- $\alpha$ ), interleukin (IL)- $1 \beta$, nuclear factor kappa B (NF- $\mathrm{KB})$, and prostaglandin $\left(\mathrm{PG}^{2} \mathrm{E}_{2}\right)$ [48]. Therefore, many phytochemicals have been tested to discover novel anti-neurodegenerative agents, which revealed that phenolic constituents are one of the major neurotrophic and anti-neuroinflammatory compounds [48,49]. In line with this finding, the isolated phenolic compounds in this study (1-24) were assessed for their anti-neuroinflammatory activities by measuring NO levels in LPS-activated BV-2 cells (Table 3) and for their neurotrophic effects evaluated by assessing 
the secretion of NGF from C6 cells (Table 4). Compounds 1-3, 8-O-4' type neolignans, significantly reduced NO levels with $\mathrm{IC}_{50}$ values of $18.63-19.75 \mu \mathrm{M}$, which showed better activity than a well-known inhibitor of NO synthase (NOS), $N^{\mathrm{G}}$-monomethyl-L-arginine (L-NMMA, $\mathrm{IC}_{50} 21.35 \mu \mathrm{M}$ ) [50]. These data were consistent with the previous studies in which diverse $8-\mathrm{O}-4^{\prime}$ type neolignans exhibited potent $\mathrm{NO}$ inhibitory activity [49]. However, compounds 4 and 5, the other $8-O-4^{\prime}$ type neolignans, were not active $(>100 \mu \mathrm{M})$ in this study, which might be attributed to the different configuration at C-7 and/or the glucopyranosyl unit attached to the molecules. The most potent compound in this study was 6, a furanofuran-type lignan, with $\mathrm{IC}_{50}$ value of $12.69 \mu \mathrm{M}$, whereas the other glucosylated furanofuran-type lignans $\mathbf{7}$ and $\mathbf{8}$ did not display NO inhibitory activity. The simple phenolic glucoside 21 was a potent NO inhibitor $\left(\mathrm{IC}_{50} 15.00 \mu \mathrm{M}\right.$ ) but transfer of the methoxy group at C-3 to C-2 decreased the potency ( $\left.\mathrm{IC}_{50} 41.67 \mu \mathrm{M}, 20\right)$. The other compounds showed weak or no activity.

Table 3. Inhibitory effects of selected compounds on nitric oxide (NO) production in lipopolysaccharide (LPS)-activated BV-2 cells.

\begin{tabular}{ccc}
\hline Compound & IC $_{\mathbf{5 0}}(\boldsymbol{\mu M})^{\mathbf{1}}$ & Cell viability (\%) $^{\mathbf{2}}$ \\
\hline $\mathbf{1}$ & 18.66 & $113.97 \pm 1.36$ \\
$\mathbf{2}$ & 19.75 & $105.99 \pm 7.78$ \\
$\mathbf{3}$ & 18.63 & $94.33 \pm 3.84$ \\
$\mathbf{6}$ & 12.69 & $101.33 \pm 8.15$ \\
$\mathbf{9}$ & 97.50 & $97.67 \pm 3.20$ \\
$\mathbf{1 2}$ & 72.50 & $114.97 \pm 5.17$ \\
$\mathbf{1 7}$ & 68.77 & $106.59 \pm 1.27$ \\
$\mathbf{2 0}$ & 41.67 & $103.50 \pm 2.62$ \\
$\mathbf{2 1}$ & 15.00 & $103.50 \pm 2.62$ \\
$\mathbf{2 4}$ & 70.08 & $94.46 \pm 10.89$ \\
L-NMMA $^{3}$ & 21.35 & $104.56 \pm 4.20$ \\
\hline
\end{tabular}

${ }^{1} \mathrm{IC}_{50}$ value of each compound was defined as the concentration $(\mu \mathrm{M})$ that caused $50 \%$ inhibition of NO production in LPS-activated BV-2 cells. ${ }^{2}$ Cell viability after treatment with $20 \mu \mathrm{M}$ of each compound was determined by 3[4,5-dimethylthiazol-2-yl]-2,5-diphenyltetrazolium bromide (MTT) assay and is expressed in percentage (\%). The results are averages of three independent experiments, and the data are expressed as mean $\pm \mathrm{SD}$. ${ }^{3} \mathrm{~N}^{\mathrm{G}}$-monomethyl-L-arginine (L-NMMA) as positive control.

Table 4. Effects of selected compounds on nerve growth factor (NGF) secretion in C6 cells.

\begin{tabular}{ccc}
\hline Compound & NGF Secretion $^{\mathbf{1}}$ & Cell Viability (\%) $^{\mathbf{2}}$ \\
\hline $\mathbf{1}$ & $110.27 \pm 2.18$ & $96.59 \pm 2.78$ \\
$\mathbf{2}$ & $127.98 \pm 3.95$ & $101.75 \pm 2.40$ \\
$\mathbf{3}$ & $149.89 \pm 1.97$ & $105.00 \pm 3.21$ \\
$\mathbf{6}$ & $120.09 \pm 2.72$ & $109.25 \pm 8.03$ \\
$\mathbf{1 2}$ & $135.10 \pm 5.59$ & $94.41 \pm 1.83$ \\
$\mathbf{2 0}$ & $157.73 \pm 1.50$ & $11.83 \pm 8.24$ \\
$\mathbf{2 1}$ & $125.00 \pm 1.50$ & $117.97 \pm 8.50$ \\
6-shogaol $^{3}$ & $149.53 \pm 5.36$ & $97.00 \pm 0.17$ \\
\hline
\end{tabular}

${ }^{1}$ C6 cells were treated with $20 \mu \mathrm{M}$ of compounds. After $24 \mathrm{~h}$, the content of NGF secretion in C6-conditioned media was measured by ELISA. The level of secreted NGF cells is expressed as percentage of the untreated control. The data shown represent the means \pm SD of three independent experiments performed in triplicate. ${ }^{2}$ Cell viability after treatment with $20 \mu \mathrm{M}$ of each compound was determined by MTT assay and is expressed in percentage (\%). The results are averages of three independent experiments, and the data are expressed as mean \pm SD. ${ }^{3}$ 6-shogaol as positive control.

\subsection{Neurotrophic Activity of the Isolated Compounds (1-24)}

Similar to the NO inhibitory activity profile of the 8-O-4' type neolignans, only 1-3 displayed effect on NGF release with stimulation levels of $110.27 \pm 2.18 \%, 127.98 \pm 3.95 \%$, 
and $149.89 \pm 1.97 \%$, respectively, while the latter was comparable to that of positive control, 6-shogaol (149.53 $\pm 5.36 \%)$ [51]. The addition of a ketone group at C-7' $(\mathbf{1})$ and removal of the methoxy group at C-5 (2) in 3 decreased NGF secretion activity. Compound 20 showed powerful NGF release effect with stimulation levels of $157.73 \pm 1.50 \%$ but this compound was cytotoxic to the tested C6 cells (cell viability: $11.83 \pm 8.24 \%$ ). Compounds 6, 12, and 21 were mild neurotrophic agents (120.09 $\pm 2.72 \%, 135.10 \pm 5.59 \%$, and $125.00 \pm 1.50 \%$, respectively) and the other compounds were inactive $(<100 \%)$.

\subsection{Cytotoxicity of the Isolated Compounds (1-24)}

Podophyllotoxin is a representative anticancer natural product with a lignan scaffold and its synthetic derivative etoposide $\left(\operatorname{VePesid}^{\circledR}\right)$ is chemotherapy medication used for the treatments of diverse types of cancer [2]. Since most of the isolated phytochemicals (1-24) are derivatives of lignan or its monomer, phenylpropanoid, their cytotoxic activity against four human cancer cell lines, A549 (non-small-cell lung adenocarcinoma), SK-OV-3 (ovary malignant ascites), SK-MEL-2 (skin melanoma), and MKN-1 (adenosquamous carcinoma) were evaluated via the SRB bioassay method with etoposide as a positive control substance ( $\mathrm{IC}_{50} 0.98,2.15,1.80$, and $3.47 \mu \mathrm{M}$, respectively). As a result, four 8-O-4' type neolignans, 1-4, and a phenolic glucoside 24 showed an inhibitory effect on MKN-1 cancer cell with $\mathrm{IC}_{50}$ values of $11.15,14.03,14.16,7.96$, and $19.04 \mu \mathrm{M}$, respectively (Table 5 ).

Table 5. Cytotoxicity of selected compounds against four cultured human cell lines.

\begin{tabular}{ccccc}
\hline \multirow{2}{*}{ Compound } & \multicolumn{4}{c}{ IC $_{\mathbf{5 0}}(\boldsymbol{\mu M}) \mathbf{1}^{\mathbf{1}}$} \\
\cline { 2 - 5 } & A-549 & SK-OV-3 & SK-MEL-2 & MKN-1 \\
\hline $\mathbf{1}$ & $>30.0$ & $>30.0$ & $>30.0$ & 11.15 \\
$\mathbf{2}$ & $>30.0$ & $>30.0$ & $>30.0$ & 14.03 \\
$\mathbf{3}$ & $>30.0$ & $>30.0$ & $>30.0$ & 14.16 \\
$\mathbf{4}$ & $>30.0$ & $>30.0$ & $>30.0$ & 7.96 \\
$\mathbf{2 4}$ & $>30.0$ & $>30.0$ & $>30.0$ & 19.04 \\
Etoposide $^{2}$ & 0.98 & 2.15 & 1.80 & 3.47 \\
\hline
\end{tabular}

${ }^{1} 50 \%$ inhibitory concentration; the concentration of compound that caused a $50 \%$ inhibition in cell growth.

${ }^{2}$ Etoposide as positive control.

\section{Conclusions}

A total of 24 phenolic compounds (1-24) including three new compounds $(\mathbf{1}, \mathbf{9}$, and 11) were isolated and characterized from the twigs of $C$. sinensis. All isolates were evaluated for their anti-neuroinflammatory, neurotrophic, and cytotoxic activities. As a result, compounds $1-3,8-O-4^{\prime}$ type neolignans, displayed significant results in all activity evaluations. Compounds 6, 12 and 21 showed anti-neuroinflammatory effects and/or neurotrophic activity. Compounds 24 displayed inhibitory effect on MKN-1 cancer cell. Through these results, it was suggested that the phenolic compounds in C. sinensis would be responsible for one of the various activities of this plant which could be the basis for the traditional use of $C$. sinensis for inflammatory diseases. Especially, $8-\mathrm{O}-4^{\prime}$ type neolignans showed promising multi-target potentials as a drug against neurodegenerative diseases.

Supplementary Materials: The following are available online at https: / www.mdpi.com/article / 10.3390/antiox10040551/s1, General Experimental Procedures: Detailed isolation process. Scheme S1. Fractionation and isolation process of compounds 1-24 from C. sinensis twigs. Figures S1-S7: HRMS, NMR, and ECD spectra of 1, Figures S8-S14: HRMS, NMR, and ECD spectra of 9. Figure S15: Extracted ion chromatograms (EICs, $m / z$ 431.1311) of chiral derivatized L- and D-rhamnopyranose purchased or obtained by hydrolysis of 9. Figures S16-S21: HRMS and NMR spectra of 11. Figure S22: Extracted ion chromatograms (EICs, $m / z$ 447.1260) of chiral derivatized D- and L-glucopyranose purchased or obtained by hydrolysis of 11. Figures S23-S26: ${ }^{1} \mathrm{H}$ and ${ }^{13} \mathrm{C}$ NMR spectra of 2 and 3. 
Author Contributions: D.H.K. performed the experiments, analyzed the data, and wrote the manuscript. L.S., and H.R.K. performed the experiments and analyzed the data. S.Y.K. and S.U.C. oversaw the biological assays. C.S.K. conceived the study, oversaw experiments, and wrote the manuscript. All authors have read and agreed to the published version of the manuscript.

Funding: This work was supported by the National Research Foundation (NRF) of Korea grant funded by the government of Korea (MSIT) (No. 2012M3A9C4048775) and by the BK21 FOUR Project.

Institutional Review Board Statement: Not applicable.

Informed Consent Statement: Not applicable.

Data Availability Statement: The data presented in this study are available on request from the corresponding author.

Acknowledgments: We are thankful to the Korea Basic Science Institute (KBSI) for the measurements on mass spectra.

Conflicts of Interest: The authors declare no conflict of interest.

\section{References}

1. Crozier, A.; Jaganath, I.B.; Clifford, M.N. Dietary phenolics: Chemistry, bioavailability and effects on health. Nat. Prod. Rep. 2009, 26, 1001-1043. [CrossRef] [PubMed]

2. Walsh, C.T.; Tang, Y. Natural Product Biosynthesis; Royal Society of Chemistry: London, UK, 2017; pp. 357-410.

3. Moon, M.; Kim, H.G.; Choi, J.G.; Oh, H.; Lee, P.K.; Ha, S.K.; Kim, S.Y.; Park, Y.; Huh, Y.; Oh, M.S. 6-Shogaol, an active constituent of ginger, attenuates neuroinflammation and cognitive deficits in animal models of dementia. Biochem. Biophys. Res. Commun. 2014, 449, 8-13. [CrossRef] [PubMed]

4. Wyss-Coray, T. Ageing, neurodegeneration and brain rejuvenation. Nature 2016, 539, 180-186. [CrossRef] [PubMed]

5. Liu, Z.; Zhang, A.; Sun, H.; Han, Y.; Kong, L.; Wang, X. Two decades of new drug discovery and development for Alzheimer's disease. RSC Adv. 2017, 7, 6046-6058. [CrossRef]

6. Mihara, S.; Tateba, H.; Nishimura, O.; Machii, Y.; Kishino, K. Volatile components of Chinese quince (Pseudocydonia sinensis Schneid). J. Agric. Food. Chem. 1987, 35, 532-537. [CrossRef]

7. Korea Institute of Oriental Medicine. MEDICLASSICS. Available online: https://mediclassics.kr/books/8/volume/6\#content_ 1437; https:/ / mediclassics.kr/books/8/volume/8\#content_396; https://mediclassics.kr/books/8/volume/13\#content_64 (accessed on 15 January 2021).

8. Lee, M.H.; Son, Y.K.; Han, Y.N. Tissue factor inhibitory flavonoids from the fruits ofChaenomeles sinensis. Arch. Pharm. Res. 2002, 25, 842-850. [CrossRef] [PubMed]

9. Lee, M.H.; Han, Y.N. A new in vitro tissue factor inhibitory triterpene from the fruits of Chaenomeles sinensis. Planta Med. 2003, 69, 327-331. [CrossRef] [PubMed]

10. Oku, H.; Ueda, Y.; Ishiguro, K. Antipruritic effects of the fruits of Chaenomeles sinensis. Biol. Pharm. Bull. 2003, 26, 1031-1034. [CrossRef] [PubMed]

11. Osawa, K.; Arakawa, T.; Shimura, S.; Takeya, K. New quinic acid derivatives from the fruits of Chaenomeles sinensis (Chinese quince). Nat. Med. 2001, 55, 255-257.

12. Lianna, S.; Yongfu, H. Chemical constituents of Chaenomeles sinensis (Thouin.) Koehne. J. Chin. Pharm. Sci. 2000, 9, 6-9.

13. Kim, H.-K.; Jeon, W.-K.; Ko, B.-S. Flavanone glycoside from the fruits of Chaenomeles sinensis. Nat. Prod. Sci. 2000, 6, 79-81.

14. Shin, J.-E.; Jin, Q.-L.; Jin, H.-G.; Woo, E.-R. Phytochemical constituents Isolated from the stems of Chaenomeles sinensis Koehne. Kor. J. Pharmacogn. 2011, 42, 223-228.

15. Gao, H.; Wu, L.; Kuroyanagi, M.; Harada, K.; Kawahara, N.; Nakane, T.; Umehara, K.; Hirasawa, A.; Nakamura, Y. Antitumorpromoting constituents from Chaenomeles sinensis KOEHNE and their activities in JB6 mouse epidermal cells. Chem. Pharm. Bull. 2003, 51, 1318-1321. [CrossRef]

16. Osawa, K.; Yasuda, H.; Morita, H.; Takeya, K.; Itokawa, H. Antibacterial and antihemolytic activity of triterpenes and $\beta$-sitosterol isolated from Chinese Quince (Chaenomeles sinensis). Nat. Med. 1997, 51, 365-367.

17. Tanaka, T.; Nakashima, T.; Ueda, T.; Tomii, K.; Kouno, I. Facile discrimination of aldose enantiomers by reversed-phase HPLC. Chem. Pharm. Bull. 2007, 55, 899-901. [CrossRef]

18. Kim, C.S.; Oh, J.; Suh, W.S.; Jang, S.W.; Subedi, L.; Kim, S.Y.; Choi, S.U.; Lee, K.R. Investigation of chemical constituents from Spiraea prunifolia var. simpliciflora and their biological activities. Phytochem. Lett. 2017, 22, 255-260. [CrossRef]

19. Blasi, E.; Barluzzi, R.; Bocchini, V.; Mazzolla, R.; Bistoni, F. Immortalization of murine microglial cells by a v-raf/v-myc carrying retrovirus. J. Neuroimmunol. 1990, 27, 229-237. [CrossRef]

20. Choi, Y.; Lee, M.K.; Lim, S.Y.; Sung, S.H.; Kim, Y.C. Inhibition of inducible NO synthase, cyclooxygenase-2 and interleukin-1 $\beta$ by torilin is mediated by mitogen-activated protein kinases in microglial BV2 cells. Br. J. Pharmacol. 2009, 156, 933-940. [CrossRef]

21. Kim, C.S.; Subedi, L.; Oh, J.; Kim, S.Y.; Choi, S.U.; Lee, K.R. Bioactive Triterpenoids from the Twigs of Chaenomeles sinensis. J. Nat. Prod. 2017, 80, 1134-1140. [CrossRef] 
22. Skehan, P.; Storeng, R.; Scudiero, D.; Monks, A.; McMahon, J.; Vistica, D.; Warren, J.T.; Bokesch, H.; Kenney, S.; Boyd, M.R. New colorimetric cytotoxicity assay for anticancer-drug screening. JNCI J. Natl. Cancer Inst. 1990, 82, 1107-1112. [CrossRef]

23. Jutiviboonsuk, A.; Zhang, H.; Tan, G.T.; Ma, C.; Van Hung, N.; Cuong, N.M.; Bunyapraphatsara, N.; Soejarto, D.D.; Fong, H.H. Bioactive constituents from roots of Bursera tonkinensis. Phytochemistry 2005, 66, 2745-2751. [CrossRef] [PubMed]

24. Gan, M.; Zhang, Y.; Lin, S.; Liu, M.; Song, W.; Zi, J.; Yang, Y.; Fan, X.; Shi, J.; Hu, J. Glycosides from the root of Iodes cirrhosa. J. Nat. Prod. 2008, 71, 647-654. [CrossRef] [PubMed]

25. Huo, C.; Liang, H.; Zhao, Y.; Wang, B.; Zhang, Q. Neolignan glycosides from Symplocos caudata. Phytochemistry 2008, 69, 788-795. [CrossRef] [PubMed]

26. Cha, J.M.; Lee, T.H.; Subedi, L.; Ha, Y.J.; Kim, H.R.; Kim, S.Y.; Choi, S.U.; Kim, C.S. Isolation and structural characterization of four diastereomeric lignan glycosides from Abies holophylla and their neuroprotective activity. Tetrahedron 2020, 131735.

27. Matsuda, N.; Kikuchi, M. Studies on the constituents of Lonicera species. X. Neolignan glycosides from the leaves of Lonicera gracilipes var. glandulosa MAXIM. Chem. Pharm. Bull. 1996, 44, 1676-1679. [CrossRef]

28. Matsushita, H.; Miyase, T.; Ueno, A. Lignan and terpene glycosides from Epimedium sagittatum. Phytochemistry 1991, 30, $2025-2027$. [CrossRef]

29. Sakakibara, A.; Sudo, K.; Kishi, M.; Aoyama, M.; Hwang, B. Hydrogenolysis of protolignin. XVI. Isolation of $\beta$-O-4 and $\beta-\beta$ type compounds. Mokuzai Gakkaishi 1980, 26, 628-632.

30. Lee, I.-S.; Jung, S.-H.; Lee, Y.M.; Choi, S.-J.; Sun, H.; Kim, J.S. Phenolic compounds from the leaves and twigs of Osteomeles schwerinae that inhibit rat lens aldose reductase and vessel dilation in zebrafish larvae. J. Nat. Prod. 2015, 78, 2249-2254. [CrossRef]

31. Nakasone, Y.; Takara, K.; Wada, K.; Tanaka, J.; Yogi, S.; Nakatani, N. Antioxidative compounds isolated from Kokuto, noncentrifugal cane sugar. Biosci. Biotechnol. Biochem. 1996, 60, 1714-1716. [CrossRef]

32. Tang, W.-Z.; Liu, Y.-B.; Yu, S.-S.; Qu, J.; Su, D.-M. New sesquiterpene lactone and neolignan glycosides with antioxidant and anti-inflammatory activities from the fruits of Illicium oligandrum. Planta Med. 2007, 53, 484-490. [CrossRef]

33. Son, Y.K.; Lee, M.H.; Han, Y.N. A new antipsychotic effective neolignan from firmiana simplex. Arch. Pharm. Res. 2005, 28 , 34-38. [CrossRef]

34. Kim, D.K.; Lim, J.P.; Kim, J.W.; Park, H.W.; Eun, J.S. Antitumor and antiinflammatory constituents Fromceltis sinensis. Arch. Pharm. Res. 2005, 28, 39-43. [CrossRef]

35. Schumacher, B.; Scholle, S.; Hölzl, J.; Khudeir, N.; Hess, S.; Müller, C.E. Lignans isolated from valerian: Identification and characterization of a new olivil derivative with partial agonistic activity at A1 adenosine receptors. J. Nat. Prod. 2002, 65, 1479-1485. [CrossRef]

36. Ohashi, K.; Watanabe, H.; Okumura, Y.; UJI, T.; Kitagawa, I. Indonesian medicinal plants. XII. Four isomaric lignan-glucosides from the bark of Aegle marmelos (Rutaceae). Chem. Pharm. Bull. 1994, 42, 1924-1926. [CrossRef]

37. Zhou, Y.; Li, L.-Y.; Ren, H.-C.; Qin, R.-D.; Li, Q.; Tu, P.-F.; Dou, G.-F.; Zhang, Q.-Y.; Liang, H. Chemical constituents from the whole plants of Pilea cavaleriei Levl subsp. cavaleriei. Fitoterapia 2017, 119, 100-107. [CrossRef]

38. Liu, Y.-F.; Shi, G.-R.; Wang, X.; Zhang, C.-L.; Wang, Y.; Chen, R.-Y.; Yu, D.-Q. Nine new compounds from the whole plants of Rehmannia chingii. J. Asian Nat. Prod. Res. 2016, 18, 509-519. [CrossRef]

39. Yamauchi, H.; Kakuda, R.; Yaoita, Y.; Machida, K.; Kikuchi, M. Two new glycosides from the whole plants of Glechoma hederacea L. Chem. Pharm. Bull. 2007, 55, 346-347. [CrossRef]

40. Machida, K.; Nakano, Y.; Kikuchi, M. Phenolic glycosides from Viburnum dilatatum. Phytochemistry 1991, 30, 2013-2014. [CrossRef]

41. Chung, M.-I.; Lai, M.-H.; Yen, M.-H.; Wu, R.-R.; Lin, C.-N. Phenolics from Hypericum geminiflorum. Phytochemistry 1997, 44, 943-947. [CrossRef]

42. Verotta, L.; Dell'Agli, M.; Giolito, A.; Guerrini, M.; Cabalion, P.; Bosisio, E. In vitro antiplasmodial activity of extracts of Tristaniopsis species and identification of the active constituents: Ellagic acid and 3, 4, 5-trimethoxyphenyl-(6'-O-galloyl)-O- $\beta$-Dglucopyranoside. J. Nat. Prod. 2001, 64, 603-607. [CrossRef]

43. Kanchanapoom, T.; Kasai, R.; Yamasaki, K. Iridoid and phenolic glycosides from Morinda coreia. Phytochemistry 2002, 59, 551-556. [CrossRef]

44. Zhong, X.-N.; Otsuka, H.; Ide, T.; Hirata, E.; Takeda, Y. Hydroquinone diglycoside acyl esters from the leaves of Myrsine seguinii. Phytochemistry 1999, 52, 923-927. [CrossRef]

45. Kanho, H.; Yaoya, S.; Kawahara, N.; Nakane, T.; Takase, Y.; Masuda, K.; Kuroyanagi, M. Biotransformation of benzaldehyde-type and acetophenone-type derivatives by Pharbitis nil hairy roots. Chem. Pharm. Bull. 2005, 53, 361-365. [CrossRef]

46. Kawahara, E.; Fujii, M.; Kato, K.; Ida, Y.; Akita, H. Chemoenzymatic synthesis of naturally occurring benzyl 6-O-glycosyl- $\beta$-Dglucopyranosides. Chem. Pharm. Bull. 2005, 53, 1058-1061. [CrossRef]

47. Lee, M.A.; Lee, H.K.; Kim, S.H.; Kim, Y.C.; Sung, S.H. Chemical constituents of Alnus firma and their inhibitory activity on lipopolysaccharide-induced nitric oxide production in BV2 microglia. Planta Med. 2010, 76, 1007-1010. [CrossRef]

48. Venkatesan, R.; Ji, E.; Kim, S.Y. Phytochemicals that regulate neurodegenerative disease by targeting neurotrophins: A comprehensive review. BioMed Res. Int. 2015, 2015, 814068. [CrossRef]

49. Teponno, R.B.; Kusari, S.; Spiteller, M. Recent advances in research on lignans and neolignans. Nat. Prod. Rep. 2016, 33, 1044-1092. [CrossRef] 
50. Ha, S.K.; Moon, E.; Ju, M.S.; Kim, D.H.; Ryu, J.H.; Oh, M.S.; Kim, S.Y. 6-Shogaol, a ginger product, modulates neuroinflammation: A new approach to neuroprotection. Neuropharmacology 2012, 63, 211-223. [CrossRef] [PubMed]

51. Park, G.; Kim, H.G.; Ju, M.S.; Ha, S.K.; Park, Y.; Kim, S.Y.; Oh, M.S. 6-Shogaol, an active compound of ginger, protects dopaminergic neurons in Parkinson's disease models via anti-neuroinflammation. Acta Pharmacol. Sin. 2013, 34, 1131-1139. [CrossRef] 